\title{
Pengembangan Media Pembelajaran Interaktif Berupa Aplikasi Komik Matematika dengan Pendekatan Kontekstual pada Materi Bentuk Aljabar Kelas VII SMP
}

\author{
Wulansari $^{1, \text { a) }}$, Tri Murdiyanto ${ }^{2, \text { b) }}$, Siti Rohmah Rohimah ${ }^{3, c)}$ \\ ${ }^{123}$ Universitas Negeri Jakarta \\ Email: a)wulan9703@gmail.com, b)tmurdiyanto@unj.ac.id, ${ }^{c}$ sitirohmah@unj.ac.id
}

\begin{abstract}
Abstrak
Penelitian ini dilatarbelakangi oleh analisis kebutuhan peserta didik dan guru di SMP Muhammadiyah 31 Jakarta. Berdasarkan hasil analisis kebutuhan, sebanyak 37,5\% peserta didik merasa kesulitan dalam mempelajari materi bentuk aljabar. Sebanyak 58,7\% peserta didik menyatakan pembelajaran matematika belum dikaitkan dengan kehidupan sehari-hari. Media pembelajaran yang diinginkan oleh peserta didik adalah komik dengan persentase $41,67 \%$. Sebanyak $83,33 \%$ peserta didik menghabiskan waktu luang dengan membuka gadget. Menurut pendapat guru, kriteria media pembelajaran yang baik yaitu media pembelajaran yang dapat membuat peserta didik merasa senang ketika belajar matematika. Penelitian pengembangan ini bertujuan untuk mengembangkan aplikasi komik matematika sebagai media pembelajaran interaktif dengan pendekatan kontekstual pada materi bentuk aljabar kelas VII SMP. Metode penelitian yang digunakan pada penelitian ini adalah Research and Developmet dengan model Bergman dan Moore. Tahapan penelitian pengembangan pada model Bergman dan Moore yaitu analisis, desain, pengembangan, produksi, penggabungan, dan validasi. Teknik pengumpulan dan analisis data dalam penelitian ini berlandaskan pada metode kombinasi dengan model embedded concurrent. Penelitian ini telah berhasil mengembangkan media pembelajaran interaktif berupa aplikasi komik matematika dengan kategori sangat layak berdasarkan hasil dari validasi ahli media, validasi ahli materi dan bahasa, uji coba kelompok kecil, dan uji coba kelompok besar dengan skor rata-rata sebesar 90,44\%. Sehingga Aplikasi komik matemaika yang dikembangkan dapat digunakan dalam proses pembelajaran pada materi bentuk aljabar kelas 7 SMP.
\end{abstract}

Kata kunci: komik matematika, bentuk aljabar, bergman, moore.

\section{PENDAHULUAN}

Kemajuan IPTEK yang berkembang sangat pesat membuat generasi muda termasuk di dalamnya peserta didik menjadi digital natives. Prensky (2001) membahas dalam artikelnya yang berjudul "Digital Natives, Digital Immigrant" tentang kesenjangan antara peserta didik yang lahir sebagai digital natives dimana hampir setiap aspek kehidupannya menggunakan teknologi dengan guru yang menggunakan metode lawas untuk mengajar. Oleh sebab itu, guru sebaiknya dapat memanfaatkan hasil dari teknologi yang dapat digunakan sebagai media pembelajaran dalam proses belajar mengajar untuk menyesuaikan dengan kondisi peserta didik agar pembelajaran menjadi lebih efektif dan menyenangkan bagi peserta didik. Karena media pembelajaran merupakan salah satu faktor penting yang ada di dalam proses pembelajaran. Sebagaimana disebutkan oleh Wibawanto (2017) bahwa beberapa faktor dalam proses pembelajaran yang mempengaruhi tercapainya tujuan pembelajaran diantaranya pendidik, peserta didik, lingkungan, metode/teknik dan media/alat pembelajaran.Salah satu mata pelajaran yang membutuhkan media pembelajaran adalah matematika. 
Matematika merupakan mata pelajaran yang sangat penting untuk dipelajari. Beberapa manfaat penting dalam pelajaran matematika menurut Aziz (2006) yaitu: (1) sarana berpikir yang jelas dan logis; (2) sarana untuk memecahkan masalah sehari-hari; (3) sarana untuk mengembangkan kreativitas; (4) sarana komunikasi yang kuat, singkat, dan jelas. Bahkan matematika harus dipelajari di setiap jenjang sekolah. Oleh sebab itu, peserta didik haruslah dapat menguasai pelajaran matematika. Namun cukup banyak peserta didik yang menganggap bahwa matematika merupakan mata pelajaran yang sulit.

Berdasarkan hasil angket yang telah disebarkan kepada 24 peserta didik di SMP Muhammadiyah 31 Jakarta diperoleh beberapa data, diantaranya yaitu sebanyak $66,67 \%$ peserta didik menyatakan bahwa matematika merupakan pelajaran yang sulit. 37,5\% peserta didik menyatakan materi yang paling sulit adalah materi bentuk aljabar. Sebanyak 50\% peserta didik menyatakan materi tersebut sulit karena terlalu abstrak, dan sebanyak 58,7\% peserta didik menyatakan bahwa pembelajaran matematika belum dikaitkan dengan kehidupan sehari-hari. 91,67\% peserta didik menyatakan media yang digunakan untuk pembelajaran matematika adalah buku. Sedangkan media pembelajaran yang paling diinginkan oleh peserta didik adalah komik, yaitu dengan persentase $41,67 \%$. Diperoleh pula data sebanyak $83,33 \%$ peserta didik menghabiskan waktu luang dengan membuka gadget.

Selain melalui angket dilakukan pula wawancara dengan dua orang guru matematika kelas VII di SMP Muhammadiyah 31 Jakarta. Berdasarkan hasil wawancara pendahuluan, materi yang paling sulit bagi peserta didik menurut guru yaitu Bentuk Aljabar serta Persamaan dan Pertidaksamaan Linear Satu Variabel (PLSV). Pernyataan ini cukup sesuai dengan hasil angket, yaitu materi yang paling sulit bagi peserta didik adalah materi bentuk aljabar. Guru menyatakan PLSV sebagai materi tersulit pun karena menurut guru tersebut peserta didik lemah pada materi bentuk aljabar. Hasil penelitian Hasibuan (2015) menunjukkan bahwa hasil belajar peserta didik dalam materi bentuk aljabar masih sangat rendah. Hal ini didukung berdasarkan data hasil penelitian yaitu hanya satu peserta didik $(3,7 \%)$ yang dapat menguasai materi bentuk aljabar dari 27 peserta didik.

Media pembelajaran yang biasa digunakan di sekolah tersebut untuk belajar matematika adalah buku dan kadang menggunakan media presentasi atau Power Point (PPt). Kriteria media pembelajaran yang baik menurut guru yang diwawancarai yaitu media pembelajaran yang dapat membuat peserta didik merasa senang ketika belajar matematika. Berdasarkan hasil analisis kebutuhan, media pembelajaran yang paling disenangi oleh peserta didik adalah komik, yaitu dengan persentase 41,67\% Pendapat guru mengenai komik sebagai media pembelajaran cenderung positif. Menurut guru komik lebih masuk ke dalam dunia peserta didik, serta komik akan menjadi media pembelajaran yang sangat menarik bagi peserta didik.

Komik adalah urutan-urutan gambar yang ditata sesuai dengan tujuan dan filosofi pembuatannya hingga pesan cerita tersampaikan (Gumelar, 2011). Media komik lebih efektif jika dibandingkan dengan media bergambar lain. Hasil penelitian yang dilakukan oleh Handayani (2010) menunjukkan bahwa pada pengetahuan, media komik mempunyai pengaruh peningkatan pengetahuan sebesar tiga kali lipat dibanding dengan media leaflet, dan pada sikap, media komik mempunyai perubahan positif terhadap sikap sebesar empat kali lipat dibanding dengan media leaflet.

Salah satu hasil analisis kebutuhan yang telah disebutkan yaitu 58,7\% peserta didik menyatakan bahwa pembelajaran matematika belum dikaitkan dengan kehidupan sehari-hari. Selain itu banyak peserta didik yang menyatakan materi sulit karena terlalu abstrak yaitu dengan persentase sebesar $50 \%$. Oleh karena itu materi matematika sebaiknya dikemas menjadi lebih konkret dan dikaitkan dengan kehidupan sehari-hari yaitu dengan menggunakan pendekatan kontekstual. Menurut Muslich (2009), pembelajaran kontekstual adalah suatu konsep belajar yang mengaitkan antara materi pembelajaran dengan situasi dunia nyata peserta didik, serta mendorong peserta didik untuk dapat membuat hubungan antara pengetahuan yang dimilikinya dengan penerapannya dalam kehidupan sehari-hari.

Berdasarkan uraian tersebut maka akan dilakukan suatu penelitian dengan judul "Pengembangan Media Pembelajaran Interaktif Berupa Aplikasi Komik Matematika dengan Pendekatan Kontekstual pada Materi Bentuk Aljabar Kelas VII SMP” agar terciptanya sebuah media pembelajaran dengan pendekatan kontekstual yang menyenangkan bagi peserta didik sebagai solusi dalam pembelajaran matematika materi bentuk aljabar. 


\section{METODE}

Penelitian ini bertujuan untuk mengembangkan dan menghasilkan media pembelajaran interaktif komik matematika dengan menggunakan pendekatan kontekstual sebagai alat bantu pembelajaran pada materi bentuk aljabar kelas VII SMP.

Metode penelitian yang digunakan dalam penelitian ini menggunakan metode Research and Development (R\&D). Menurut Putra (2011), metode R\&D adalah metode penelitian yang secara sengaja, sistematis, bertujuan untuk mencaritemukan, merumuskan, mengembangkan, memperbaiki, menghasilkan, menguji keefektifan produk, model, metode, jasa, atau prosedur tertentu yang lebih baru, unggul, efisien, efektif, dan bermakna. Putra (2011) juga menyebutkan bahwa metode R\&D menekankan untuk menghasilkan produk yang berguna dalam berbagai bentuk sebagai inovasi dari bentuk-bentuk yang sudah ada. Inovasi dalam pendidikan bersifat lebih mikro, terkait metode dan model pembelajaran, rekayasa kurikulum, peralatan atau teknologi pembelajaran, dan instrumen pengukuran (Putra, 2011).

Model pengembangan produk yang dilakukan berdasarkan model pengembangan Bergman dan Moore yang pertama kali dikembangkan tahun 1990. Model ini dipilih karena menurut Tegeh, Jampel, dan Pudjawan (2014) model pengembangan Bergman dan Moore secara umum dapat digunakan untuk pengembangan produk pembelajaran interaktif. Model Bergman dan Moore juga menekankan pada evaluasi output pada setiap langkah sebelum proses berikutnya. Hal tersebut dilakukan agar tidak terjadi banyak kesalahan saat proses pengembangan media pembelajaran. Oleh karena itu, penelitian ini menggunakan model Bergman dan Moore untuk dijadikan acuan dalam pengembangan media pembelajaran interaktif aplikasi komik matematika yang disingkat Kommika.

Model Bergman dan Moore terdiri dari enam aktivitas utama yaitu (1) analisis, (2) desain, (3) pengembangan, (4) produksi, (5) penggabungan dan (6) validasi (Tegeh, Jampel, \& Pudjawan, 2014). Setiap langkah didahului oleh input, selanjutnya menghasilkan suatu output dan akhirnya output dievaluasi. Diagram alir rancangan model pengembangan Bergman dan Moore dapat dilihat pada gambar 3.1 sebagai berikut.

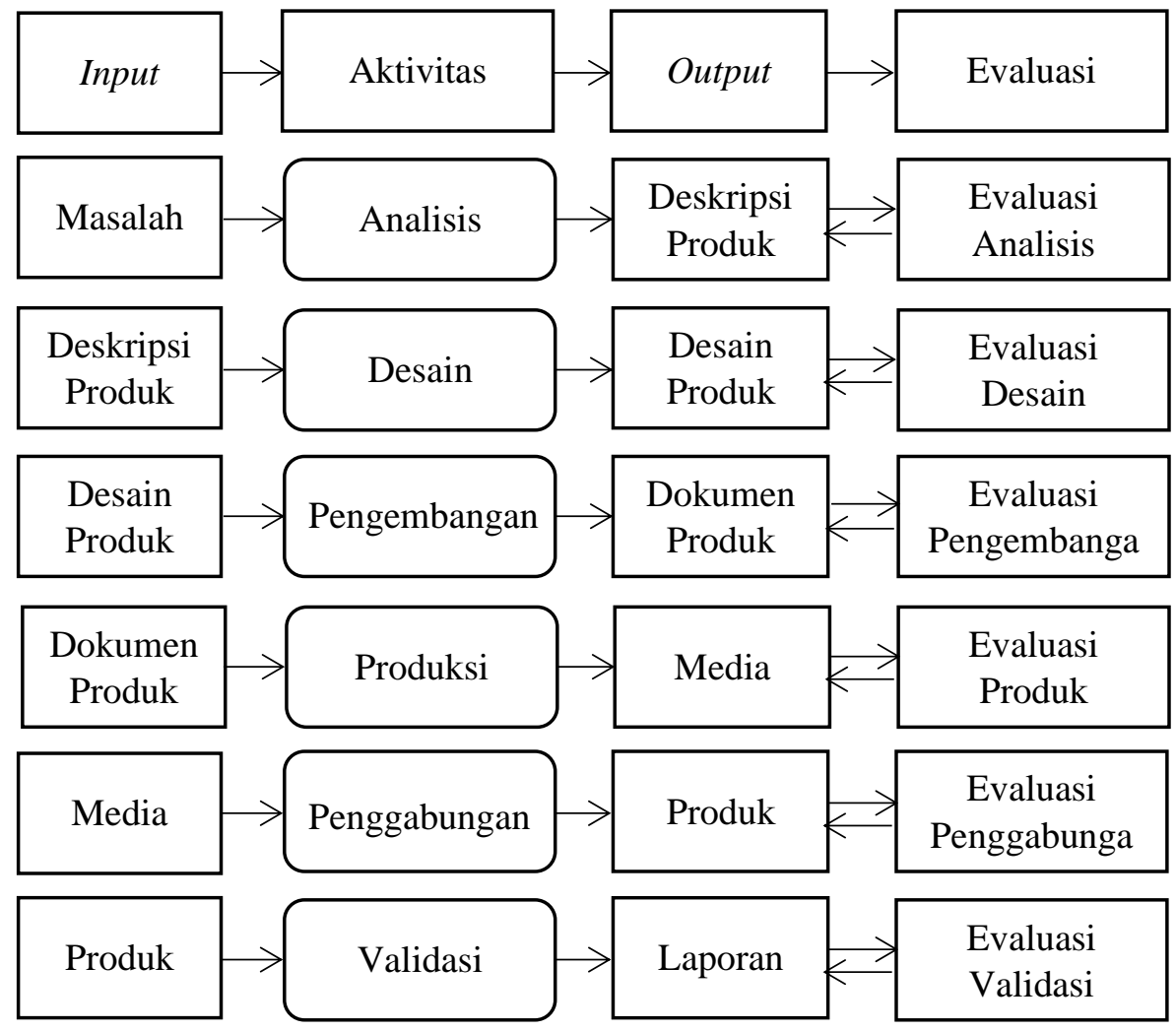

GAMBAR 1. Model Bergman dan Moore (Tegeh, Jampel, \& Pudjawan, 2014) 
Data dalam penelitian ini diperoleh dengan dua cara, yaitu pemberian angket dan wawancara. Angket atau questionnaire merupakan daftar pertanyaan yang didistribusikan melalui pos untuk diisi dan dikembalikan atau dapat juga dijawab di bawah pengawasan peneliti (Nasution, 2008). Sedangkan wawancara adalah suatu bentuk komunikasi verbal semacam percakapan yang bertujuan untuk memperoleh informasi (Nasution, 2008). Sebelum responden diberikan angket serta melakukan wawancara, peserta didik diminta untuk mencermati produk yang diberikan. Kemudian responden diminta untuk memberikan penilaian, kritik serta saran yang nantinya akan digunakan dalam pengembangan produk yaitu berupa media pembelajaran interaktif.

Teknik analisis data yang digunakan pada penelitian ini menggunakan metode kombinasi. Metode kombinasi adalah suatu metode penelitian yang mengkombinasikan antara metode kuantitatif dan metode kualitatif untuk digunakan secara bersamaan dalam suatu penelitian, sehingga didapatkan data yang lebih valid, reliabel, komprehensif, serta obyektif (Sugiyono, 2017). Adapun model yang digunakan adalah model embedded concurrent. Model embedded concurrent merupakan salah satu metode penelitian kombinasi yang lebih menitikberatkan pada metode kuantitatif sebagai metode primer sedangkan metode kualitatif sebagai metode sekunder (Subagyo, 2020). Data yang diperoleh dengan menggunakan metode kualitatif bersifat subyektif, untuk meningkatkan obyektivitasnya, dapat dilakukan dengan mengggunakan metode kuantitatif (Sugiyono, 2017).

Data kuantitatif yang dihasilkan adalah data yang berasal dari hasil angket yang diisi oleh responden menggunakan skala penilaian dari 1 sampai 5. Skala penilaian merupakan suatu skala pengukuran yang diinterpetasikan dalam pengertian kualitatif. Data yang diperoleh selanjutnya disajikan dalam persentase. Persentase hasil angket selanjutnya diinterpretasikan dalam beberapa kategori. Tabel 3.1 menjelaskan ketentuan pemberian nilai menggunakan skala likert.

TABEL 1. Ketentuan pemberian nilai (Sugiyono, 2016)

\begin{tabular}{cc}
\hline Kategori & Nilai \\
\hline SS (Sangat Setuju) & 5 \\
S (Setuju) & 4 \\
Netral & 3 \\
TS (Tidak Setuju) & 2 \\
STS (Sangat Tidak Setuju) & 1 \\
\hline
\end{tabular}

Hasil data yang terkumpul akan dianalisis dengan menghitung persentase skor dari setiap aspek pada kuesioner yang diperoleh dengan menggunakan rumus:

$$
\text { persentase }=\frac{\text { jumlah skor yang didapat }}{\text { jumlah skor maksimum }} \times 100 \%
$$

Persentase hasil penilaian yang diperoleh akan dikonversikan kembali menjadi kategori kelayakan media pembelajaaran sehingga dapat diambil kesimpulan mengenai kelayakan media pembelajaran. Berikut adalah tabel pedoman konversi ideal yang dijabarkan pada Tabel 2.

TABEL 2. Pedoman konversi skor (Sudijono, 2012)

\begin{tabular}{cc}
\hline Rentang & Klasifikasi \\
\hline $0 \%-20 \%$ & Sangat Tidak Layak \\
$21 \%-40 \%$ & Tidak Layak \\
$41 \%-60 \%$ & Kurang Layak \\
$61 \%-80 \%$ & Layak \\
$81 \%-100 \%$ & Sangat Layak \\
\hline
\end{tabular}




\section{HASIL DAN PEMBAHASAN}

\section{Hasil Pengembangan Model}

Pengembangan model pada penelitian ini dilaksanakan dengan menggunakan model Bergman dan Moore. Langkah-langkah pengembangan model Bergman dan Moore terdiri dari enam tahap, yaitu analisis, desain, pengembangan, produksi, penggabungan, dan validasi. Tahap yang pertama adalah tahap analisis. Tahap analisis ini dilakukan dengan cara memeriksa berbagai aspek yang terlibat dalam pengembangan produk, sehingga diperoleh kesimpulan bahwa dibutuhkan pengembangan media pembelajaran berupa aplikasi komik matematika materi bentuk aljabar dengan menggunakan pendekatan kontekstual. Aplikasi komik tersebut diharapkan mudah dioperasikan, menampilkan gambar yang menarik, terdapat pertanyaan interaktif (dapat dijawab oleh peserta didik dengan cara menekan tombol), dan dapat meningkatkan motivasi peserta didik.

Output yang didapat pada tahap analisis selanjutnya digunakan sebagai input pada tahap desain, yaitu mengembangkan media pembelajaran berupa aplikasi komik matematika. Kegiatan yang dilakukan pada tahap desain, yaitu merancang urutan segmen program secara umum serta desain rincian dari aplikasi komik matematika.

Tahap yang ketiga adalah tahap pengembangan. Hal yang dilakukan pada tahap pengembangan yaitu menyiapkan dokumen untuk tahap produksi berdasarkan output pada tahap desain. Dokumen yang perlu disiapkan yaitu Garis Besar Isi Media (GBIM), naskah cerita, neemu (gambar kasar), flowchart (diagram alir) dan storyboard aplikasi.

Tahap yang keempat adalah tahap produksi. Tahap produksi yaitu menerjemahkan output dari tahap pengembangan. Naskah cerita dan nеeти diimplementasikan melalui kegiatan menggambar untuk menghasilkan isi komik. Storyboard aplikasi yang telah dibuat pada tahap pengembangan kemudian diimplementasikan menjadi desain tampilan antar muka (interface) pada aplikasi. Gambar komik dan gambar yang disajikan pada tampilan interface dibuat dengan menggunakan software Adobe Illustartor CS6, software Adobe Photoshop CS6, dan aplikasi MediBang Paint. Software Adobe Illustartor CS6 digunakan untuk membuat line art. Software Adobe Photoshop CS6 digunakan untuk tahap pewarnaan dasar, editting, dan penambahan teks. Sedangkan aplikasi MediBang Paint digunakan untuk pewarnaan gelap terang.

Tahap yang kelima yaitu tahap penggabungan. Kegiatan yang dilakukan pada tahap penggabungan yaitu menggabungkan semua gambar, audio dan teks ke dalam suatu produk yang utuh, yaitu berupa aplikasi. Pembuatan aplikasi komik matematika menggunakan software Android Studio 4.2. Tahap penggabungan ini memiliki tiga sub aktivitas yaitu pengkodean, pengujian, dan penyetelan.

Penyajian komik matematika dengan pendekatan kontekstual dilengkapi dengan 7 komponen:

1) Kontruktivisme

Materi pembelajaran pada komik ini tidak dijelaskan secara langsung, melainkan peserta didik dituntun agar dapat membangun pemahaman mereka dari pengalaman baru berdasarkan pengetahuan terdahulu yang dimilikinya.

2) Inkuiri

Peserta didik belajar menggunakan keterampilan berpikir kritis yang merupakan berpikir tingkat tinggi untuk memecahkan permasalahan-permasalahan yang ada di dalam komik.

3) Bertanya

Terdapat pertanyaan yang berkaitan dengan materi pada setiap episode untuk menguji pemahaman peserta didik. Pertanyaan tersebut bersifat interaktif, dimana peserta didik dapat mengklik tombol opsi jawaban yang disajikan.

4) Masyarakat belajar

Peserta didik dapat berdiskusi dengan teman belajarnya untuk menjawab pertanyaan interaktif. Jika peserta didik berada di sekolah, maka peserta didik dapat berdiskusi dengan teman semejanya. Jika peserta didik berada di rumah, maka peserta didik dapat berdiskusi dengan keluarganya yang ada di rumah. 
5) Pemodelan

Setiap episode dalam komik menampilkan pemodelan yang berbeda-beda agar siswa berpikir, bekerja, berbuat dan belajar.

6) Refleksi

Disediakan rangkuman materi yang memuat isi materi bentuk aljabar untuk membantu peserta didik dalam mengingat kembali materi yang telah dipelajari.

Pengembangan aplikasi komik matematika selanjutnya divalidasi oleh para ahli yang terdiri dari dua ahli media serta dua ahli materi dan bahasa. Ahli media yang menilai aplikasi komik matematika ini adalah seorang dosen dari prodi ilmu komputer yaitu Med Irzal, M. Kom. dan seorang komikus atau animator yaitu Monica Ayu Octaviani, S.Pd yang telah memenangkan banyak penghargaan, salah satunya menjadi Nominator Film Animasi Police Movie Award 2018. Sedangkan ahli materi dan bahasa yang menilai aplikasi komik matematika ini adalah seorang dosen dari prodi pendidikan matematika yaitu Aris Hadiyan Wijaksana, M.Pd. dan seorang guru matematika di SMP Negeri 1 Babelan yaitu Fajarwati, S.Pd.

Validasi kepada para ahli dilakukan sejak 16 November sampai 8 Desember 2020. Validasi oleh para ahli ini dilaksanakan agar aplikasi komik matematika pada materi bentuk aljabar yang telah dikembangkan mendapat masukan berupa komentar, saran, dan penilaian dari para ahli di bidangnya. Masukan dari para ahli selanjutnya dijadikan bahan perbaikan yang dapat dijadikan sebagai bukti bahwa aplikasi komik yang telah dikembangkan telah layak untuk digunakan dalam pembelajaran.

\section{Pembahasan}

Penelitian pengembangan media pembelajaran aplikasi komik matematika ini telah dilakukan berdasarkan enam tahap model pengembangan Bergman dan Moore. Tahapan-tahapan tersebut yaitu analisis, desain, pengembangan, produksi, penggabungan dan validasi.

Setelah keenam tahapan dilaksanakan, selanjutnya aplikasi komik diujicobakan kepada peserta didik yang terdiri dari dua tahapan, yaitu uji coba kelompok kecil dan uji coba kelompok besar. Uji coba kelompok kecil dilakukan dengan memilih 13 peserta didik kelas VIII SMP Negeri 1 Babelan yang memiliki kemampuan heterogen dan telah mempelajari materi bentuk aljabar. Peserta didik terlebih dahulu menginstal aplikasi Kommika yang dapat diunduh melalui Google Play Store. Uji coba ini dilakukan dalam satu kali pertemuan pada tanggal 9 Desember 2020 melalui aplikasi Zoom dan WhatsApp bagi peserta didik yang tidak bisa masuk zoom meeting. Uji coba dilakukan secara online dikarenakan sekolah yang masih menerapkan PSBB di masa pandemi Covid-19.

Berdasarkan uji coba kelompok kecil diperoleh komentar dan saran yang dapat digunakan sebagai acuan revisi untuk meningkatkan kualitas produk aplikasi komik. Setelah produk direvisi berdasarkan komentar dan saran dari peserta didik pada uji coba kelompok kecil, selanjutnya dilakukan uji coba kepada kelompok besar. Uji coba kelompok besar ini dilakukan kepada peserta didik dengan jumlah lebih banyak dari jumlah peserta didik pada uji coba kelompok kecil. Uji coba kelompok besar dilakukan kepada sebanyak 50 peserta didik kelas VIII SMP Negeri 1 Babelan. Peserta didik pada uji coba kelompok besar ini memiliki tingkat kecerdasan yang heterogen dan telah mempelajari materi bentuk aljabar. Uji coba kelompok besar ini dilakukan pada tanggal 10 Desember 2020.

Keseluruhan hasil penilaian komik pada tahap validasi produk kepada para ahli, serta uji coba kepada peserta didik skala kecil dan besar dapat dilihat pada tabel berikut:

TABEL 3. Hasil Penilaian Produk

\begin{tabular}{ccc}
\hline Penilaian Produk & Skor \% & $\begin{array}{c}\text { Kategori } \\
\text { Kelayakan }\end{array}$ \\
\hline Validasi Ahli Media & $88,61 \%$ & Sangat Layak \\
Validasi Ahli Materi dan Bahasa & $91,83 \%$ & Sangat Layak \\
Uji Coba Kelompok Kecil & $93,27 \%$ & Sangat Layak \\
Uji Coba Kelompok Besar & $88,06 \%$ & Sangat Layak \\
Rata-Rata Persentase & $90,44 \%$ & Sangat Layak \\
\hline
\end{tabular}


Berdasarkan tabel hasil penilaian produk, rata-rata dari penilaian seluruh penilaian produk yang telah dilakukan maka aplikasi komik matematika yang dikembangkan memperoleh persentase sebesar 90,44\%. Dengan demikian, aplikasi komik matematika materi bentuk aljabar yang dikembangkan memperoleh kategori sangat layak. Sehingga aplikasi komik matematika yang dikembangkan dapat dimanfaatkan untuk proses pembelajaran oleh peserta didik kelas VII SMP.

\section{PENUTUP}

\section{Kesimpulan}

Pengembangan media pembelajaran aplikasi komik matematika melalui enam tahap model pengembangan Bergman dan Moore, yaitu analisis, desain, pengembangan, produksi, penggabungan dan validasi. Proses pembuatan aplikasi komik matematika melibatkan software Adobe Illustrator CS6 untuk menggambar line art, Adobe Photoshop CS6 untuk pewarnaan dasar, editting, dan pemberian teks, aplikasi MediBang Paint untuk pewarnaan gelap terang, serta Android Studio 4.2 untuk pembuatan aplikasi.

Penelitian dan pengembangan yang telah dilakukan menghasilkan aplikasi komik matematika yang dapat digunakan pada perangkat smartphone berbasis Android. Pendekatan yang digunakan dalam penyampaian materi adalah pendekatan kontekstual yakni materi yang disampaikan dikaitkan dengan kehidupan sehari-hari. Materi yang dibahas adalah materi bentuk aljabar untuk peserta didik kelas VII SMP. Terdapat fitur pertanyaan interaktif di dalam cerita dimana opsi jawaban yang diberikan dapat ditekan, dan apabila tombol jawaban ditekan maka akan muncul respon jawaban disertai dengan backsound.

Penilaian produk dilakukan oleh dua ahli media dengan skor $88,61 \%$, serta dua ahli materi dan bahasa dengan skor $91,83 \%$. Hasil uji coba kelompok kecil memperoleh skor 93,27\%, dan hasil uji coba kelompok besar memperoleh skor $88,06 \%$. Sehingga penilaian aplikasi komik matematika memperoleh skor rata-rata 90,44\% dengan kategori sangat layak. Oleh sebab itu, aplikasi komik matematika yang dikembangkan telah layak untuk digunakan dalam proses pembelajaran matematika pada materi bentuk aljabar untuk kelas VII SMP.

\section{Saran}

Berdasarkan hasil penelitian dan pengembangan aplikasi komik matematika ini, maka terdapat beberapa saran untuk penelitian pengembangan media pembelajaran selanjutnya yaitu:

a. Aplikasi komik matematika ini sebaiknya bisa diinstal pada semua jenis smartphone, seperti smartphone berbasis iOS dan Windows. Versi minimum Android juga sebaiknya dibawah versi 7.0 (Nougat) yaitu versi 6.0 (Marsmallow).

b. Mengingat hasil produk penelitian dan pengembangan dapat memberikan manfaat dalam pembelajaran, maka disarankan produk ini lebih dikembangkan lagi pada materi lain di waktu mendatang.

c. Akan lebih baik jika aplikasi komik ini memiliki daftar cerita yang lebih banyak.

d. Perlu dilakukan penelitian lebih lanjut untuk mengukur efektivitas hasil belajar matematika dengan menggunakan aplikasi komik matematika.

\section{REFERENSI}

Astuti, E. P. (2016). Mathematical connection ability junior high school students in mathematics problem solving. International Conference On Education, 1-5.

Aziz, Rini Utami. (2006). Jangan Biarkan Anak Kita Berkesulitan Belajar. Solo: Tiga Serangkai.

Gumelar, M. S. 2011. Comic Making. Jakarta: PT Indeks

Handayani, Sri. (2010). “Perbandingan Efektifitas Pemberian Informasi Melalui Media Cerita 
Bergambar (Komik) Versi BKKBN dengan Media Leaflet." Gaster, Vol. 7, No. 1, hlm. 482-490.

Hasibuan, Irwitadia. (2015). "Hasil Belajar Siswa pada Materi Bentuk Aljabar di Kelas VII SMP Negeri 1 Banda Aceh Tahun Pelajaran 2013/2014”, Jurnal Peluang, Vol. 4, No. 1, hlm. 5-11.

Muslich, Masnur, Yustianti \& Fatna. (2009). KTSP Pembelajaran Berbasis Kompetensi dan Kontekstual: Panduan Bagi Guru, Kepala Sekolah Dan Pengawas Sekolah (Cetakan ke-4). Jakarta: Bumi Aksara.

Nasution, S. (2008). Metode Research: Penelitian Ilmiah (Cetakan ke-10). Jakarta: Bumi Aksara.

Prensky, M. (2001). "Digital Natives, Digital Immigrants.” On the Horizon, Vol. 9, No. 5, hlm. 1-6.

Putra, Nusa. (2011). Research \& Development. Jakarta: Rajawali Pers.

Sudijono, Anas. (2012). Statistik Pendidikan. Jakarta: Rajawali Pers.

Sugiyono. (2016). Metode Penelitian Kuantitatif, Kualitatif, dan R\&D. Bandung: Alfabeta.

Sugiyono. (2017). Metode Penelitian Kombinasi (Mixed Methods). Bandung: Alfabeta.

Tegeh, I Made, I Nyoman Jampel, dan Ketut Pudjawan. (2014). Model Penelitian Pengembangan. Yogyakarta: Graha Ilmu.

Wibawanto, Wandah. (2017). Desain dan Pemrograman Multimedia Pembelajaran Interaktif. Jember: Cerdas, Ulet, Kreatif. 